\title{
Do We Have the Right? How Polish Same-Sex Female Families Negotiate Turning Parenting Desires into Parenting Reality
}

\author{
Magdalena Wojciechowska \\ University of Lodz, Poland
}

DOI: https://doi.org/10.18778/1733-8069.17.2.04

Keywords:

Same-Sex Female

Parenting in Poland;

Parenting Decision-

Making Process;

Heteronormative

Framework; Making

Meaning; Symbolic

Interactionism

\begin{abstract}
This paper aims to shed light on how various micro- and macro-level contexts shape the parenting decision-making process among same-sex female couples. Drawing on my six-year study of two-mother planned families in Poland, I focus on voicing their experiences related to the process of family formation from its genesis and their related desires to fit in the social fabric despite being different. Specifically, I illustrate how those who navigate within the unfavorable socio-cultural climate give meanings to their experiences thereof, and thus negotiate their moral right to become mothers, as well as what kind of interactional and contextual factors shape how same-sex female couples in Poland embrace motherhood as an option they can choose. That is, how they decide to do what is largely considered normal-to enlarge their families.
\end{abstract}

Magdalena Wojciechowska, Ph.D., is an Assistant Professor in the Department of Sociology of Organization and Management, Institute of Sociology, Faculty of Economics and Sociology, University of Lodz. Her research interests lie in the studies of members of marginalized social groups.

\section{Contact details:}

Department of Sociology of Organization and Management Institute of Sociology, Faculty of Economics and Sociology

University of Lodz

ul. Rewolucji 1905 r. nr 41/43, 90-214 Lodz, Poland

e-mail: magdalena.wojciechowska@uni.lodz.pl 


\section{Contextualizing Remarks: Same-Sex Female Families in Poland}

I mean, I never believed that it would be an option and, secondly, I somehow got used to the thought that I will never have children, and I got so used to it that such a topic was actually absent from my life.

Micro-level interactions and making meaning may be my primary focus in this paper; still, as Ryan-Flood (2009) aptly observes, embedding those in a wider socio-cultural context is crucial to understanding the situation of same-sex couples and how they decide to become parents. Thus, the above utterance by a woman who raises her biological child with her female life partner aims to illustrate the specificity of engaging in the parenting decision-making process in the case of same-sex female households in Poland. For although motherhood is framed in Poland as the obvious stage of life of every woman, in reality, it seems to be a role reserved for those who occupy a normal identity, that is, for those who fit heteronormative standards. Something that Stacey (1996) and Herek (2004; 2007) would frame in terms of living in a heterosexist and homophobic society, where lesbian motherhood-an oxymoron-is seen as, at best, inadequate-since a child needs both a mother and a father. As Majka-Rostek (2014) observes, such a perception embraces the patriarchal approach to motherhood-socially approved in the case of those who are thought best equipped to socialize the child due to navigating within the heteronormative framework. ${ }^{1}$ Furthermore, such views can be interpreted as a manifestation of so-

\footnotetext{
${ }^{1}$ Additionally, as Mizielińska and Stasińska (2020) note, the prevalent understanding of family gender roles in Poland is traditional (patriarchal). In the light of the related ideological norm of monomaternalism (see: Lubbe 2013; Majka-Rostek 2014), that implies that social mothers may not be seen as parents of their children.
}

cial control guarding the traditional order, whose effectiveness is exemplified by the fact that the very first question some women ask themselves when considering to enlarge their same-sex family is whether they have a moral right to become mothers at all. Acting so demonstrates to what extent having internalized the heteronormative rules of the game shapes their everyday experiences, but it also exemplifies that "the 'negation' of identity is what separates the marginalized group from the dominant group" (Gouliquer, Poulin, and McWilliams 2020:50). Based on her research on same-sex couples in Poland, Majka-Rostek (2008; 2011) discussed how prevalently unfavorable social attitudes towards the LGBT community shaped their everyday life decisions, including leading some kind of a double life (also see: Mizielińska, Abramowicz, and Stasińska 2015). Her observations in that regard seem to be in line with the experiences of two-mother families in Poland, who often attempt to conceal the nature of their familial ties in front of certain people and in certain situations, for example, when acting within institutionalized or common public spaces (see, e.g., Wojciechowska 2014; 2015; 2020a; 2020b; Mizielińska, Struzik, and Król 2017; Mizielińska and Stasińska 2020). According to the report on the "Attitude to People of Homosexual Orientation" (CBOS 2017:4):

One sixth of respondents (16\%) regard homosexuality as something normal...Over half of Poles (55\%) treat homosexuality as a deviation from the norm, which should be tolerated, while every fourth respondent (24\%) thinks that it should not be tolerated. The last attitude in this decade is much less frequently expressed than previously...Most Poles are reluctant to extend to homosexual couples norms and rights of heterosexuals. Over the years, however, we have seen some change in this respect. One third of respondents $(32 \%)$ are in favor of same-sex couples publicly show- 
ing their way of life. Slightly fewer approve of their right to enter into marriages $(30 \%)$, and one-ninth (11\%) think that they should have the right to adopt children.

Furthermore, the heteronormative culture-surfacing from social anxiety and discomfort related to how same-sex families challenge people's definition(s) of what can be framed as "traditional family" (Goldberg, Downing, and Richardson 2009)-is manifested in Polish law. As Wojciechowska (2014; 2015; 2020a; 2020b) and Mizielińska, Struzik, and Król (2017) observe, it is at this level of their everyday acting where two-mother families experience their marginalization-invisibility-most severely. First, same-sex couples living in Poland receive no legal recognition. Second, Polish law only grants for the acquisition of parental rights based on biological and/or formal ties (i.e., relatives or a spouse of the child's parent) and does not allow for adoption by same-sex couples. Third, since 2015 access to assisted reproductive technologies is granted only to heterosexual couples (married or unwed). ${ }^{2}$ Finally, equally unfavorable seems to be the public attitude towards the LGBT community in general, exemplified by such initiatives as "LGBT-free zones." ${ }^{3}$

Being socialized within a heteronormative society that sees the LGBT community as deviant (in Goffmanian sense) makes the individual cognizant of how they may be perceived in the case of moving down the socially constructed ladder of normalcy (see: Warner 1999) - that is, if they decide to enlarge their families. That, in turn, makes them anticipate-at every step of the way-the consequences

\footnotetext{
${ }^{2}$ All of the participants in this study conceived before the introduction of the legislation at hand.

${ }^{3}$ See: https://www.nytimes.com/2020/07/30/world/europe/LGBTfree-poland-EU-funds.html. Retrieved September 20, 2020.
}

such a decision may entail for their child to be born, and-in that local context of unfavorable socio-cultural climate-is likely to take the form of probing their good fit as mothers (see, e.g., Bos, van Balen, and van den Boom 2007; Mezey 2013; Wojciechowska 2020a).

Mezey (2013) highlights that psychological barrier(s), which largely manifest in structural obstacles to create a family, may sway same-sex female couples away from their desires to become mothers. That is, the belief that only heterosexual, preferably married, women make fit mothers, coupled with people's view of same-sex parenting as a threat to the moral fabric of (traditional) society, surfaces in legislations preventing same-sex families from marrying or adopting a child-everything that Polish same-sex female couples encounter daily. How does it shape the way they consider enlarging their families? To begin with, they are to some extent symbolically torn between complying with societal expectations to do so and not fitting definitional categories of family life-an example of Goffman's (1959) role strain. Thus, before deciding that a child can enter their family, same-sex couples engage in intense emotional work aimed at embracing the anticipated long-term implications of navigating within the heteronormative socio-cultural context(s) as a two-mother family. For instance, while considering to enlarge their family through artificial insemination of one of the partners with the sperm of an anonymous donor, which was the case for each of the families in this study, the participants had to embrace that they may not be afforded the same allowances that are made for normal families. That is, although she participates in raising her child, the non-biological mother cannot make any legally sanctioned decision concerning the offspring, in the case of the women's separation, the child will not 
receive legally-established alimony, and in the event of the death of the biological mother, the offspring may be legally taken away from the other mother. Thus, the circumstances of those individuals who did not give birth to their children seem to be even more complex-for non-biological mothers are invisible both socially, as well as in the eyes of the law, which, as Park (2013) observes, is underpinned by the socio-cultural norm of monomaternalism. In this sense, they can be viewed as those lower down on the ladder of normalcy, as Warner (1999) framed it, and thus largely rely on their personal, interactional, financial, and cultural resources when it comes to negotiating multiple identities, many of which (i.e., non-biological lesbian mother)-in the case of Poland-have poor socio-cultural underpinning (see: Wojciechowska 2015; 2020a).

Bearing in mind the unfavorable socio-cultural climate contextualizing the way same-sex female couples in Poland engage in the parenting decision-making process, one may ask how they negotiate their right to become mothers, decide which one of them will give birth to their child, and what kind of interactional and/or socio-cultural factors shape parenting considerations among them. Those questions-the answers to which highlight how parenting is socially constructed-are discussed in the following empirical sections of the paper.

One of my aims here is to reconstruct and discuss how same-sex female couples in Poland decide to enlarge their families while making sense of diverse interactional and socio-cultural contexts-as experienced and recounted by the research participants. Thus, the analytical paths that I follow emerge from reflection on constructing social reality (Berger and Luckmann 1966) and the theoretical framework of symbolic interactionism. Specifically, I focus on how, while interpreting the world around them, the participants give meanings in the process of negotiating their whatness and howness (Kleinknecht 2007). I assume that the influence of any element of the reality external vis-à-vis the individual is mediated by a continual process of interpretation, when one attributes their experiences specific meanings (Blumer 1969; Strauss 1993). In this sense, human acting emerges in the course of constant construction of unstable meanings-for every action, interaction, and phenomenon are continually defined and adapted to the individual's interpretations (Prus 1997). Thus, human experiences can be viewed in terms of social products-emerging and/or ongoing constructs shaped by numerous interactional, cultural, and contextual settings (Prus and Grills 2003).

Still, before I move on to discussing the circumstances of how Polish same-sex female couples turn parenting desires into parenting reality, the following analyses will be embedded within the broader context of studies on non-heteronormative motherhood.

\section{What Do We Know about Non- Heteronormative Motherhood and Parenting Decisions among Lesbians?}

Female same-sex couples who bring up children together are referred to in the literature as one of the alternative forms of the family (see, e.g., Coleman and Ganong 2004; Slany 2006; Peterson and Bush 2013) that exemplify the concept of "family of creation" (Slater 1995) or "family of choice" (Weston 1991). Besides, although the phenomenon at hand has been of scientific interest for only the past few decades, it does not seem to be new (Paldron 2014). In the past, those beyond the heteronormative framework certainly also became mothers, although-due to the 
specific socio-cultural climate-it could have been, as Clarke suggests (2008), within the context of hiding their non-heteronormative identity, for example, due to entering into a heterosexual relationship. As Clarke (2008) further argues, the deletion of homosexuality from the Diagnostic and Statistical Manual of Mental Disorders in 1973 was one of the factors that contributed to the increase in the visibility of non-heteronormative motherhood in the social fabric, leading to what is framed in Western literature as Lesbian Baby Boom (Patterson 1995). Since then, two-mother families have been given much more scholarly attention.

Johnson (2012) identifies three waves of research on such families. The first wave (the late 1970s) included studies involving women whose children were born in opposite-sex relationships-before entering into a same-sex relationship, in which the children were raised. The second wave (the 1980s and 1990s) concerned planned families, that is, those where the partners made a decision to enlarge their family in the course of their relationship. As Johnson (2012) claims, such studies largely ignored the experiences of those co-creating the family, primarily focusing on the issue of a child's progress within a non-heteronormative family. The third (ongoing) wave of research shifts the analytical emphasis from the issue of normality of the family towards reflecting on the actual experiences of same-sex female families. Of course, although the scope of the above research areas can also be traced in non-Western studies, their focal point in understanding the situation of same-sex female families is, nonetheless, legal and socio-cultural context(s) (see, e.g., Zhabenko 2014; 2019; Mizielińska and Stasińska 2020; Wojciechowska 2020a). In part, this is due to tensions that arise within specific geopolitical (and in this sense-local) contexts that further complicate the everyday reality for LGBT communities. For instance, a turn towards institutionalizing the so-called "traditional family values" (Zhabenko 2019), which, in Poland, may be exemplified by limiting access to assisted reproductive technologies or LGBT-free zones, does not leave intact how same-sex female families both plan and practice their families. In this sense, showing that local embedment plays a central role in studying same-sex female families allows highlighting, among others, how the mutual distrust between those on different levels on the socially constructed ladder of normalcy translates into social reality they negotiate for everyone involved-with same-sex female families being more reluctant than before to reveal the nature of their relationships, and the normative society at large more persistent in opposing their right to live like (a normative) everyone else. Such local tensions may make researching same-sex female families more challenging (e.g., in terms of reaching the study participants), and the development of non-Western research less linearwhen compared to Western studies, where the participants' legal situation is regulated.

As Clarke (2002) argues, most scholarly work searches for differences and similarities between non- and heteronormative motherhood. As a result, many discourses problematize two-mother families in relation to what Clarke (2002) refers to as "four dimensions of difference" that inform theorizing and research on non-heteronormative motherhood. "These construct lesbian parenting as (i) no different from heterosexual parenting; (ii) different from heterosexual parenting and deviant; (iii) different from heterosexual parenting and transformative; and (iv) different from heterosexual parenting only because of oppression" (Clarke 2002:210). As Linder (2011) highlights, the focus on how same-sex mothering is different-but not worse-from heteronor- 
mative one can be seen in terms of defending the right of those beyond the traditional family life to raise their children. Yet, such studies seem to approach people's experiences in a non-specific and quite marginal way. Moreover, according to Stacey and Biblarz (2001), although unintentionally, they could have contributed to the embedment of some commonly understood social constructs, for example, that of femininity or family.

The emphasis on showing that bringing up a child in a non-heteronormative family is not a threat to their normal progress, since there are no significant differences between the two (non- and heteronormative families), fits in, as Ryan-Flood (2009) observes, the so-called assimilative approach. It is within this perspective that same-sex families were advocated to be viewed as just as normal as heteronormative ones. Still, as mentioned before, although such research can contribute to the legal provisions and/or greater social acceptance for two-mother families, they can also, as Clarke (2002) claims, have an impact on the strengthening of the heteronormative framework-precisely by making it the ultimate point of reference on the ladder of normalcy. Further, Ryan-Flood (2009) highlights that in the transformative approach, where the emphasis is placed on the differences between nonand heteronormative families in relation to the well-being of children they raise, some "superiority" is awarded to the parenting styles adapted by the former, who seem to lean towards more egalitarian models. Still, as Ryan-Flood (2009) further observes, such a utopian approach can contribute to an increase in social control, as well as expectations of women who raise a child in a same-sex family. For not only should they meet the standards of more traditional families, but they should also become even better guardians. Thus, the op- tics at hand also seem to be based on the rules of the game that are embedded in the heteronormative framework.

In more recent work, the analytical emphasis is placed on capturing the experiences of those who co-create non-heteronormative families (see, e.g., Goldberg and Allen 2013). They discuss, for instance, issues related to the quality of their lives or whether two-mother families consider themselves happy-given that some of them make their status open-ended due to concealing the nature of their family in front of certain people and in certain situations (see, e.g., Weeks, Heaphy, Donovan 2001; Chambers 2006; Wojciechowska 2020a). Still, as Mezey (2013) argues, scholarly discourse is primarily focused on same-sex female families after children enter into those families. Thus, there is a significant gap in our understanding of the process of same-sex families' formation from their genesis. And yet, as she further advocates, studying their intentional parenting decisions-to become mothers or to remain childfree-can inform our understanding of families in general in numerous ways. First, since almost all same-sex families do plan their parenthood, investigating intentional parenting decisions may shed light on how people create stable families regardless of their sexual identity. Moreover, as Mezey further observers, having a choice in that regard allows seeing motherhood as such, not in terms of an obligation to women. Second, understanding that parenthood develops out of specific social contexts can inform our knowledge of how it is socially constructed in general. Third, having identified the factors that help people make parenting decisions both makes us aware of the kinds of support that they may need, as well as provides a model for researching other types of families (Mezey 2013). Finally, such 
research can shed light on why "postmodern families" (Stacey 1996) develop and change at particular moments in time, thus adding to the traditional family landscape. Based on the studies conducted in different countries-and thus, in diverse socio-cultural contexts-that Mezey (2013) reviewed in the chapter "How Lesbians and Gay Men Decide to Become Parents or Remain Childfree," she identified some key factors that shape their parenting decision-making process. Among them are "personal issues [e.g., the desire to become a parent or remain childfree and internalized homophobiaMW], access to support networks, work-related issues, and relationships with intimate partners" (Mezey 2013:60). Of course, those are also shaped by other factors, like the structure of class or race. Thus, it is vital to understand how macro-level social, structural, and institutional factors have an impact on the micro-level parenting decision-making process among same-sex households. In a nutshell, "social support in the way of supportive families, communities, jobs, partners, and society in general helps lesbians and gay men create healthy families" (Mezey 2013:69). The process at hand, if they wish to become mothers at all, is also easier for White, middle-class women. First, since they hold greater economic and social power. Second, since the communities they are intertwined with do not necessarily overlap with their familial social ties (see: Mezey 2013).

In the following empirical sections of the paper, I will discuss how same-sex female couples negotiate to embrace the idea of enlarging their families while navigating within the unfavorable socio-cultural climate; explain the role that both existing and ad hoc social networks play in their decision-making process; and present key factors that shaped their decisions to enlarge the family.

\section{Methodological Note}

Analyses presented in this paper are based on my six-year study of two-mother planned families in Poland. ${ }^{4}$ All of the 21 same-sex couples who participated in the study decided to enlarge their families due to intrauterine insemination or in vitro fertilization of one of them with the sperm of an anonymous donor (all couples have only one child). At the time of our first meeting, the women in this study were between 26-40 and, with the exception of the five couples expecting, the children's ages varied from 2 months to 6 years old. Before they decided to become mothers, the women had been together for 1.5 to 5 years. One of the couples separated before their child reached one year of age, but they still raise the offspring together. All of the participants in the study are University graduates who live in big cities or their suburban areas. Most of the couples enjoyed social, cultural, and economic capitals allowing them, in their opinion, to protect themselves, as well as their child, against the anticipated emanations of homophobia (all but one couple enjoyed a family network supportive of both their sexual identities and desires to become mothers).

Specifically, I conducted semi-structured interviews and participant observations of planned two-mother families. ${ }^{5} \mathrm{I}$ interviewed both women together and separately about their experiences

\footnotetext{
${ }^{4}$ A more detailed presentation and analysis of the issues discussed in this paper can be found in: Wojciechowska 2020a.

${ }^{5}$ I also interviewed three lesbian couples who raise a child being a biological descendant of one of them (conceived during her marriage ended with divorce). Still, since the situation of reconstructed families is different from what planned families encounter (see: Wojciechowska 2015; 2020a), data obtained from the former mostly served comparative purposes, and are not included in the paper. In the course of the research, I also interviewed one gay couple where one of the partners has a child being raised by his ex-wife.
} 
and everyday lives. ${ }^{6}$ In the case of the interviews with both partners, I paid special attention to avoid any sensitive, or potentially so, issues, which, if emerged, were brought to light at the time of individual meetings. ${ }^{7}$ Moreover, since most of the couples do not reveal the nature of their relationship in certain situational contexts and/or in front of certain people, the participants involved have been anonymized. The interviews were recorded and transcribed. All quotations from the interviews presented in this paper have been translated from Polish. In sum, I conducted 76 interviews with the women whose child had been artificially conceived in the course of their relationship-30 interviews with both mothers and 46 individual interviews (21 with biological mothers and 25 with non-biological mothers ${ }^{8}$ ). The interviews lasted around three to five hours (in the case of interviews with both partners) and around one to two hours (in the case of individual interviews). To aid in the triangulation of the data (Denzin 1978), I interviewed couples at different periods across the 6 years span of the project. $^{9}$ That allowed me to see how things had

\footnotetext{
${ }^{6}$ The research participants' children (usually toddlers) were present at the time of the interviews with both partners. Still, none of the women insisted on keeping it short. Moreover, some of them viewed sharing their stories in terms of the opportunity to raise-via potential publications-social awareness of two-mother families in Poland. On the other hand, I do not exclude that such motives could have an impact on the way they constructed their narrations.

${ }^{7}$ Five couples were not interviewed separately and-due to time constraints-we met only once.

${ }^{8}$ It was the participants' choice to be referred to in potential publications as non-biological mothers-they viewed this term as the closest to their situation, and to how they felt, in the socio-legal context.

${ }^{9}$ One of my aims while conducting the project was to see whether/how the research participants' situation evolved. Thus, I intended to interview the couples at-a minimumtwo points in time. I interviewed 8 couples twice $(2$ families in 2014 and 2016, 3 couples in 2015 and 2017, and 3 other families in 2016 and 2018) and 4 families 3 times ( 2 families in 2013, 2015, and 2017 and 2 other couples in 2014, 2016, and 2018).
}

changed over time and added a longitudinal element to the study. Additionally, I conducted overt participant observations during the everyday life activities of the participants, which added an ethnographic element to the research design. Three families allowed me to accompany them in their everyday life activities such as going to the park, to the shopping mall, to the zoo, picking the child up from nursery school, or playing with the child in the yard or at the playground. To date, I have conducted 28 observations lasting around one to three hours, with the notes being taken during or right after the observation.

All data gathered during the course of the study have been analyzed according to grounded theory methodology procedures (Glaser and Strauss 1967; Konecki 2000; Charmaz 2006), which entailed, among others, coding (open, selective, and theoretical coding), theoretical sampling and constant comparative method, memoing, diagramming, sorting memos and diagrams towards theoretical integration of categories. Following the procedures of theoretical sampling and constant comparative method, I have been deciding on what data to collect next, as well as where to find them, in order to understand how various dimensions of the participants' everyday lives are interconnected, and thus construct a theory grounded in the data. To put this into the analytical context, at first, the scope of the project was much wider-encompassing the situation of same-sex female and male families in Poland. Still, since during the course of the study the issue of parenting emerged as a vital category (mostly in the narrations of women, but also in those of men), I followed their lines of verbalized experiences. Additionally, I interviewed both planned, as well as reconstructed families. Nonetheless, since the situation of the latter turned out to be quite differ- 
ent from what planned families encounter, ${ }^{10}$ data obtained from the reconstructed families mostly served comparative purposes. Furthermore, having conceptualized my research inquiry as exploring the experiences of same-sex female planned families residing in Poland, I intended to see whether/how their situation, perceived as marginalized by the study participants, evolves, as their children grow up and thus become a (more) aware interactional actors; or whether/how other contextual, situational, and interactional factors shape their experiences in the area of non-heteronormative motherhood. This, in turn, allowed me to reconstruct and explain theoretical links between categories. The results of thusly conducted explorations-in relation to one of the analytical categories, that is, embracing motherhood as possible-underpin my further discussions.

Since my goal was also to understand and retell the participants' reality the way they experience it, in the next sections of the paper, I give voice to the families made of two mothers of one child. The remaining sections of the article discuss how making sense of specific micro- and macro-level contexts shapes the parenting decision-making process among samesex female couples. Drawing on verbalized experiences of the participants, I exemplify how the way they negotiate and give meanings to their specific social positionality in terms of planning to take on a new-socially invisible role-is underpinned by being socialized within heteronormative society. In this sense, analyzing diverse interpretational and interactional contexts of how they decide to become mothers allows shedding light on how parenting is socially constructed.

\footnotetext{
${ }^{10}$ For instance, due to the simple fact of the presence of the child's father (or their mother) within institutionalized social spaces (see: Wojciechowska 2020a).
}

\section{Embracing the Idea of Becoming Mothers: Between Fear and Desire}

When meeting the participants for the first time, I usually started the interview with a general request, Please tell me about yourself, with the hope that doing so would allow me to smoothly proceed to more specific questions regarding their everyday experiences, as well as to collect some contextualizing information about the family. Acting thusly proved to be helpful in learning about issues such as the length of their relationship (or for how long they have been together before they started considering enlarging the family), the child's age, their occupations, relations with the families of origin, access to support networks, et cetera. Interestingly, though, it allowed me to discover one other thing about them-some of the participants stated that although their child was $x$ years old, they had been mothers for a much longer period, largely exceeding the time needed to get pregnant and that of pregnancy. On the one hand, this can be explained in relation to their desire to become mothers (Mezey 2008; 2013), but it can also be viewed in terms of the manifestation of internalized heteronormativity, not to say homophobia by the society at large (Stacey 1996; Herek 2004; 2007; Mezey 2013), which may have shaped their parenting decision-making to a large degree. ${ }^{11}$ That is, although they wish to start a normal family, they do not quite fit in structurally as non-heteronormative partners and parents. Hence, whatever they do, their actions and consequences

\footnotetext{
${ }^{11}$ My intention here is to embrace that being socialized in a heteronormative society, and thus-knowing its rules of the game, allows the participants to perceive their specific social positionality through the lenses of the generalized other. Thus, being aware that their situation (but also that of their child to be born) may not be seen as normal, and thus-problematic to either of them or the child-they negotiate the very possibility of becoming mothers, which one of the women-whose utterance is cited here-explicitly phrased as "the right...to have a child."
} 
thereof seem to be interpreted in the course of taking on the perspective of the generalized other-for they are aware that their right to live a normal life may be questioned. Their anxieties and fears in this regard are voiced by Iza, a non-biological mother whom I met in 2014:

Look, we met in 2007, and it has been years since then, I mean, YEARS, before our late-night talks turned into something more. In fact, I remember those times as such "whether years." Whether we can live together, whether we can love one another, whether we can go out as a couple, whether we can have a child, a CHILD, I mean, back then... It's too much to talk about... Well, you know, it has been years, honestly, years, before I even started considering whether we have the right, precisely that-the right, as a lesbian couple, to have a child together.

Having internalized that displaying a non-heteronormative identity may challenge people's definition(s) of normality and, in the case of same-sex couples, that of family, those beyond the heteronormative framework must learn to live (and deal) with their stigma (Goffman 1986). In consequence, referring to what they know best, that is, the local heteronormative framework of meanings, they may start considering their fit to become parents in the specific socio-cultural context they live in, which has been verbalized in terms of the "whether years." Thus, before they begin wondering about how, they first consider whether, as voiced by Iza, they have the moral right to become mothers at all. In a nutshell, doing so is largely underpinned by anticipating the possibility of experiencing some form of discrimination, directed towards either of them or their future child (Wojciechowska 2014). Hence, some of the participants intentionally silenced their potential desires to become mothers.
For me, it was pretty obvious, right. I mean, a long, long time ago I've been tricking myself into thinking that I didn't like kids, but it was simply to not feel something towards those kids. However, later on, I had a lot to do with kids, and it turned out that I did like them, but I never dared to think that I could have children of my own. If someone had asked me like two years ago, or three years ago, if I would have a child, I would have replied, with complete confidence, that I would not.

[Agata, non-biological mother, 2013]

"Tricking oneself into thinking" that they wished to remain childfree can be seen in terms of protecting oneself against the (anticipated) feeling of deprivation. ${ }^{12}$ Hence, keeping a sense of agency in that regard allowed the participants to rationalize their situation due to secondary socialization of emotions (Stets and Turner 2006). This exemplifies how they take on the perspective of the generalized othertheir interactional partner-while considering becoming mothers.

In the same vein, Asia's example speaks to how, through the social control of one's psychosexual identity, the internalization of what fits in the moral fabric of society lures the participants into believing that their desires to become mothers are selfish, and thus irresponsible in the context of a child's ontological well-being (see: Giddens 1991; Konecki 2018). Additionally, embracing to enlarge their family in terms of fulfilling their "egoistic needs" at the expense of the child's well-being, and thus taking into account their social fit as mothers (as negotiat-

\footnotetext{
${ }^{12}$ Of course, my aim here is not to imply that the desire to become a parent is a universal value. Instead, I wish to explain how women in this study deal with anticipating that, at some point in time, they may wish to become mothers, which, in the case of those beyond the heteronormative framework, may be seen in terms of going down the ladder of normalcy.
} 
ed with one of their focal interactional partnersthe generalized other), resonates with Iza's verbalized uncertainty of whether their "right...to have a child" will be symbolically granted.

Asia: Oh, I wished, of course that I wished to be a mom to such a Little One, but, you know, wanting something doesn't mean being able to have it... I mean, I wished to have a normal family... Okay, perhaps you can delete the part about a normal family [laughs]. But, well, I was brought up to believe that when people love each other, they have a child. And so I wanted it so much, but, tell me, how can one bring a Little One into such a world?

Me: Into such a world?

Asia: Well... I mean... a very uncertain world.

Me: Uncertain?

Asia: Hey, let's don't pretend. Poland is not the most tolerant country, right, and such a decision is a huge responsibility when you consider a child's future, especially that of a child, so we have been in two minds for quite a while, considering whether it was not out of our egoistic needs that [their child] was to come into the world [referring to the situation before she got pregnant].

[Asia, biological mother, 2015]

The above utterance aptly illustrates how engaging in the parenting decision-making process is shaped by the issue of what, and for whom, is considered normal; and by doing so, it also elucidates how the concept of family is socially constructed. For Asia, as well as for many of the other participants, family is to be understood in relation to how it is practiced, not in terms of its structure (see: Morgan 1996). Furthermore, such a way of operationalizing the concept at hand allows seeing the family-related decision-making as an integral part of the reflexive project of the Self (Giddens 1991), regardless of sexual identity.
As reflected in this section, what unifies the participants' experiences in the course of considering becoming parents is a surfacing concern about their child being raised in two-mother families. In consequence, their anxieties in that regard informed the way they engaged in negotiating their moral right to become mothers. As Ala, a non-biological mother whom I interviewed in 2013, observes:

Well, first of all, one has to feel that they want to be a parent to a child...there are couples, like Ewa and I, who made an informed decision, and there is no... You know, you need to think it through, you really have to give it a good thought 'cause there's no turning back, so you really have to know what it is that you want to be able to make the decision...but, you know, there's a difference between "wanting a child," I want, I want, but introducing them later on into this world, as a conscious parent-those are two different things.

Seeing their decision to enlarge the family as a turning point, the participants in this study approached their parenthood in terms of a reflexive project, which allowed them to embrace the related concerns as some sort of an asset. For reflecting on their moral right to become mothers gave way to make meaning of parenthood by drawing a line between "having a child" and "being a parent," which, as Ala's narration illustrates, exemplifies taking longterm responsibility for their decisions. In this sense, understanding and embracing their parenthood as the planned one can be seen in terms of one of the anchors based on which the participants may normalize their situation and recognize their right to start their two-mother families.

Having outlined how embracing the idea of becoming mothers as negotiated with the generalized 
other may factor into turning parenting desires into parenting reality, I will now move on to reflecting on the role social networks play in the process at hand.

\section{Those Who Are Alike and Those Who Love Us: Support Networks}

An important factor shaping the participants' parenting decision-making process is how they are integrated into the so-called support networks. That is, whether they can find and/or access people in a situation similar to their own (i.e., other same-sex female couples considering enlarging their families or two-mother families in Poland), as well as what kind of relations they have with their closest interactional circles-their families of origin. As Mezey (2013) argues, support from those beyond the heteronormative framework can shape their parenting decision-making process in terms of giving them the confidence that they could choose to become parents and access the resources needed to realize that desire. The participants in this study, the majority of whom enjoyed their families of origin's acceptance of their sexual identities, reported discussing with them the issue of enlarging their families on a number of occasions. Still, before making and sharing their decisions in that regard, first, they often resorted to those similar to them, and thus that is where I begin.

\section{Gaining Access to Information: Informal Networks}

What I have realized at a relatively early stage of the research was that while seeking out information and resources, the participants have been developing a strong network of ties, bonding with people in a situation similar to their own, many of whom they had met via Internet channels. Interestingly, some of the participants hoped for expanding such informal networks due to contributing to the study. Thus, getting to know more or, as in the case of some of them, any same-sex female couples facing similar fears and doubts represented for them a tangible benefit of participating in the project.

The above observations hark back to the specific socio-cultural climate that shapes the way same-sex female couples in Poland engage in the parenting decision-making process. For embracing their socio-legal invisibility makes them answer an important question, that is, how to logistically achieve their goal(s). As explained in the methodological section, all of the participants enlarged their families due to intrauterine insemination or in vitro fertilization of one of them with the sperm of an anonymous donor. Interestingly, their rationale behind so doing was underpinned by locally embedded fear-involving some man in the process (i.e., a known donor) would pose a threat of him being legally bound to their child. That resonates with the findings by Mizielińska and Stasińska (2020) - where two planned same-sex female families voiced such a solution as potentially weakening the position of a social mother. Still, even though they knew how they wished to conceive, the participants embraced that finding a suitable path towards medical services may not be easy. For instance, the study by Goldberg and colleagues (2009) reports that physicians often ignore those partners who are not trying to get pregnant, which, in turn, may lead the couples to question their decision to become mothers. ${ }^{13}$ As Mezey (2013) aptly observes, the quality of emotional treatment by physicians may lead to delaying or dismissing one's

\footnotetext{
${ }^{13}$ The issue of institutional marginalization in Poland of those partners who did not give birth to their children is addressed in: Wycisk 2017.
} 
impulses to become a mother. Thus, knowing which physician and/or clinic to go to may be key to helping same-sex female couples to realize their parenting desires. Hence, understanding that their attempts to get pregnant may challenge people's definition(s) of family, thus resulting in receiving no or discriminatory treatment, some of the participants in my study did not reveal the nature of their relationships, instead presenting themselves as single women. Still, having realized that acting so can prove difficult for the not-trying partner, the majority of the participants wished to be equally engaged at every step of the process. Therefore, their existing or ad hoc informal networks (i.e., those reached via the Internet after the issue of enlarging the family surfaced) were utilized, as the participants reported, to seek out information regarding issues such as conceiving and giving birth (e.g., how to choose a clinic, how to behave during the first and subsequent appointments, where family delivery is an option for same-sex couples, etc.), dealing with not being seen, and treated, like normal families, getting some kind of legal advice, et cetera. As the participants explained:

Me: Ladies, please tell me what prompted you to choose this clinic.

Paulina: We were guided by only one criterion here, that is, that we both could, from the very beginning, be in this together, so hence the choice of this particular clinic, and not another one, where we had no information [from acquaintances who have already undergone the procedure] how it looked like there.

Weronika: Exactly, so here we expected higher costs, I don't even mean accommodation, commuting, but... well, that was the first criterion for us-that we are together in this from the very beginning...

Paulina: With no related stress.

[Paulina, non-biological mother, Weronika, biological mother, 2015]
Me: Ok, so what made you look for such advice?

Natalia: I think that we simply needed some kind of external confirmation that, you know, that, first, it can be achieved in such a human way, and, second, that, simply speaking, there are people like us, who have done it and who live a normal life.

Me: Normal life?

Natalia: Yes, simply put, who are not persecuted in any way just because they are a lesbian couple with a child, and... that this child is safe, because this is the most important thing for me.

Me: And did you succeed? I mean, in finding that confirmation that you were looking for.

Natalia: Not in black and white terms, as that is never the case [laughs], but as we got in touch, I simply realized that that's somebody else's life, but it can be my life, too.

[Natalia, biological mother, 2016]

A surfacing remark is that access to such support networks played yet another role-it allowed the participants to understand that they were not alone. In this sense, access to other peoples' experiences not only could have soothed their concerns, but also made them embrace non-heteronormative motherhood in terms of available reality. Additionally, as voiced by the participants, they wished to plan the beginning of their motherhood on their terms. As I discussed elsewhere (see: Wojciechowska 2015; 2020a), one way to achieve it was acting as (paying) customers-thus able to-to a certain degree-control the course of an interaction. This resonates with Mizielińska and Stasińska's findings (2020), where they observe, "securing the normal treatment meant in fact buying it...They bought themselves an illusionary comfort and for a while managed to escape the heteronormativity of public institutions in Poland." Additionally, as exemplified in my study, the notion of such "illusionary comfort" also entails that the way women interpret their interactional positioning within public space does not necessarily 
change along with experiencing non-discriminatory treatment that they "bought." For instance, more often than not, when faced with affirmative reactions of, or normal treatment from, those outside their close interactional circles, who have correctly decoded their familial situation (e.g., physicians, store clerks, neighbors, or people at the playground), they welcomed such reactions with angst and, more importantly, surprise (see: Wojciechowska 2020a). On the one hand, that, again, highlights how the heteronormative rules of the game shape their everyday experiences. On the other hand-it contextualizes why developing a network of ties seems appealing for those who-due to local embedment-have little ready-made interactional scripts at their disposal. ${ }^{14}$

In short, for the participants in this study, support networks provided a variety of functions, including: 1) access to vital information, 2) acting as space where both mothers could openly participate, and 3) were an outlet where they could share experiences with those similar to them. In this sense, being able to access people in a situation similar to their own not only can inform the way they engage in the parenting decision-making process, but can also be seen as yet another anchor based on which they may normalize their situation.

\section{Negotiating the Interactional Order: Families of Origin}

My parents have always dreamed of a grandchild! Simply put... They would always say that they would take care of them, babysit, just like grandparents do, right. They probably thought it would never come true, and then, poof, we made them such a surprise [laughs].

[Nina, biological mother, 2015]

\footnotetext{
${ }^{14}$ Such support networks may play a key role when the parenting desires become parenting reality (see: Wojciechowska 2020a).
}

Although well-aware that the society at large may not approve of their way of living, which they have learned to deal with at a much earlier date, the participants in this study (all but one couple ${ }^{15}$ ) enjoyed supportive interactional circles in the form of their families of origin. Furthermore, the majority of them emphasized at the time of the interviews that their closest interactional circles' opinions and support played a vital role in turning their parenting desires into parenting reality.

Monika: Okay, so let me just add that, as a matter of fact, what was very, very important in our case was how our parents would approach this "baby plan" of ours, 'cause, you know, to be honest, we've been counting on a little help [laughs].

Kasia: So true, though it's not that we wanted them to babysit, no, not such a kind of help...we simply wished for their support. In the sense that they're okay with that, that they accept that, and, based on that, we wished to build the family of ours.

[Monika, non-biological mother, Kasia, biological mother, 2015]

Julia: Of course, we had quite a few family discussions about that. We talked quite a lot with our parents, with Agnieszka's granny, for example, we talked about how it would be, about such, say, practical, though no less important, stuff...And their opinion was very important for us-their insights, whether we were on the same page there.

Me: For what reason was it so important to you?

\footnotetext{
${ }^{15}$ The lack of acceptance from the part of their families of origin, as well as from the local community, drove them to move to a much bigger city, where they started building a supportive network of friends. In 2017, they moved again-this time to the UK where they raise their child to date. At the request of both their families, they do not keep in touch with them, although the mother of one of them knows that their child was born. As I have been informed, she was not pleased to hear that.
} 
Julia: Short answer-because we are a family, and I believe that in the case of any second thoughts, then such matters should be discussed in the family circle. [Julia, non-biological mother, 2016]

As discussed earlier, engaging in the parenting decision-making process was seen by the participants as a turning point, and thus sharing their plans in that regard with their families of origin was something that they all embraced in terms of the natural order of things. That is, understanding their family as being part of a larger interactional circle, the participants wished to leave intact their supportive networks, rightly assuming that their families would approve of their decision to become mothers. Additionally, their next-of-kin are those who will have an impact on the child's socialization, and thus their approval of the participants' choices to become mothers may be of key importance. Still, their hopes for their families' "support" and "being on the same page," harking back to the specificity of the participants' situation, can also be viewed in terms of an attempt to take on their perspective-that of normals. In this sense, engaging their significant others in the parenting decision-making process can be seen through two analytical lenses. First, making sure that they, indeed, are "on the same page" stands for the participants' reflexivity and responsibility in approaching their decisions to become mothers, which, based on making meaning of how they address their choices, can be seen as their symbolic attempt at legitimizing their decisions. Second, since the participants anticipated their families to be supportive of their decisions to put their parenting plans into practice, engaging them in the decision-making process can be viewed as anchoring the participants' moral right to become mothers-as a normalizing strategy aimed at obtaining (anticipated) external confirmation that the path they have chosen to follow is, indeed, right. Furthermore, engaging their next-of-kin in the parenting decision-making process can be seen as negotiating the interactional order of the family they build together-as laying foundations for future interactions where the study participants will act as normal agents who can count on the support, be it symbolic or tangible, from their families of origin. ${ }^{16}$

On the other hand, as Natalia's remark illuminates, sharing their parenting decisions with their families of origin, and hoping for their support, has yet another context-related dimension-that of two-mother families' legal invisibility.

Natalia: Telling our parents was a must for me... I mean, for me, it is only natural to share such things with those who love you, who have your back no matter what. Like, at this point...

Karolina: If I may add one thing...

Natalia: I'm talking here, but, yeah, go ahead, don't mind me [laughs].

Karolina: Okay, sorry about that, just wanted to bring one thing up. It's true that they love us and that we can always count on them, but there's one more thing to that-at the end of the day, they're the ones who decide, and, as I see it, that was important, too.

Natalia: Oh yeah, that's yet another issue that we've been dealing with...

[Natalia, biological mother, Karolina, non-biological mother, 2016]

The issue of "who decides at the end of the day," brought up by the woman who did not give birth

\footnotetext{
${ }^{16}$ An example of laying foundations for future interactions is agreeing on naming practices with the participants' families of origin. Still, as I witnessed at the time of observations, the participants do not always stick to what, as I have been told, had been decided in that regard. Thus, the repertoire of their practices seems to be context-specific (see: Wojciechowska 2020a).
} 
to her child, stands for one of the most difficult obstacles that two-mother families in Poland face on a daily basis. That is, receiving no legal recognition, which, for them, translates into one simple question-What happens when the biological mother is gone ${ }^{17}$ Simply put, negotiating the interactional order of the family with the supportive next-of-kin can be seen in terms of securing the participants' future. Thus, their anticipated, and disclosed, attitudes towards not only the participants' decision to enlarge the family, but also the family itself may be of great importance in the parenting decision-making process. For instance, as stressed by Marzena, one of the participants in Mizielińska and colleagues' (2017) study, the lack of acceptance from the part of her parents, which would have excluded her partner from familial practices if Marzena had become a biological mother, informed which one of them (the partner) first gave birth to their child.

Having embraced the specific context of their situation, the participants in this study had to face a number of logistically informed questions, including which one of them will give birth to their child, the answers to which shaped their parenting decision-making process. Thus, in the next section of this paper, I will discuss pragmatic factors that had an impact on their choices in that respect.

\section{On the Continuum of Emotional yet Pragmatic Choices: Contexts \& Resources That Shape Parenting Decisions}

When I discuss my research in a variety of private contexts, many people tend to ask me the same question: How is that even possible? Of course, such

\footnotetext{
${ }^{17}$ A detailed analysis of the issue at hand, in relation to the situation of same-sex female families after children enter into those families, can be found in: Wojciechowska 2020a.
}

queries, mostly referring to how same-sex couples can conceive, can be seen as an example of socio-cultural invisibility of non-heteronormative parenting, which, as explained before, translates into its legal invisibility. One of the issues that the participants need to embrace each time someone asks them which one of them is the mother. As Milena's utterance illustrates:

You know, it's just that they have to name me in some way. That is, it seems to me that it's in our nature to call things by their names, and, when it comes to me, well, no name would apply here, right?

[Milena, non-biological mother, 2017]

Be it social or co-mother, there is a pool of terms in the literature from which to choose when addressing those who did not give birth to their children (Brown and Perlesz 2007). Still, the verbalized lived experiences of the participants in this study seem to challenge those terms in relation to their everyday encounters, shaped, to a large degree, by the context-specific heteronormative framework (see: Ryan-Flood 2009) - the norms of which they, as well as other people, have internalized. That is in line with the accounts offered by the participants in Mizielińska and colleagues' (2017) study, that they-those mothers who did not give birth to their childrenhave no name. Thus, since that implies that the participants' roles as mothers may be seen as unequal, ${ }^{18}$ the above considerations can make us wonder how same-sex female couples in Poland decide which one of them will give birth to their child, the more so that all of the participants in this study revealed their desires to become mothers.

\footnotetext{
${ }^{18}$ The issue of how non-biological mothers negotiate their roles once the children have entered into their families exceeds the scope of this paper, and thus is not addressed here. Its analysis can be found in: Wojciechowska 2015; 2020a.
} 
You may find that amusing, but when I think about that now [deciding which one of them would give birth to their child], it all comes down to such... practical things. Like, I mostly work from home, and paddling one's own canoe translates into being able to be a stay-at-home mom with little damage to my work. Also, I'm older, and since every year may make a difference at some age, we thought that it would be wiser if I go first... ${ }^{19}$

[Ewa, biological mother, 2017]

Interestingly, as exemplified by Ewa's utterance, when recounting their choices in that regard, the participants referred, for the most part, to what they have framed as "practical" issues, such as work-, age-, health-, and economic-related questions. For instance, as Ewa-and many other participantsexplained, their choices have been shaped by which one of them was older (to not limit her chances of getting pregnant in the future) or who had a job more, or less, favorable to motherhood in terms of economic security, as well as providing them with flexible schedules to accommodate a variety of parental responsibilities and activities. Additionally, as already noted, their financial security proved to be of key importance in the parenting decision-making process, which is exemplified by the fact that all of the families in this study reported saving money to be able to enlarge their families, which was to facilitate their navigating within the unfavorable contexts, and thus enable them to face the anticipated problems. As some of the participants explicit-

\footnotetext{
${ }^{19}$ Some of the couples considered having a family with two children, so that each of the partners could be a biological mother of one of them. Additionally, for some, such an idea symbolically represented the glue that would hold the family together. Still, while meeting those participants in the subsequent years, it turned out that none of them decided to do so in the course of the study. While some explained that in terms of being the child's mother regardless of kinship, or by referring to the stability of the family as it were, many of those women brought up the issue of everyday parental hardships, whichat the time being-made them revise their plans.
}

ly articulated, if they earned the national average salary, they would not have the courage to enlarge their families. That is in line with Mezey's (2013:66) insights that "those who hold middle-class jobs not only earn a comfortable salary...but also their jobs often come with flexibility and solid benefits, including sick leave, vacation time, and health insurance." Thus, the way the participants approached their parenting choices may be seen in terms of pragmatic actions aimed at maximizing both their chances to become mothers and their ontological security thereof. Still, as Ewa goes on, the picture at hand becomes more complex,

but, there is always a "but," 'cause even now as we speak, it is quite obvious to me that we wouldn't have been making our choice based on such criteria if it weren't for our situation. And, frankly speaking, it makes me sick how so many of our choices are made like that... When you think about that, it's not even a real choice, 'cause, in the back of your mind, you always go like, "What if..." Like it were not about you, but about what happens in our "colorful" country.

[Ewa, biological mother, 2017]

What surfaces from Ewa's utterance is that, in reality, the pool of choices that the participants have is largely framed by socio-cultural and legal restrictions, as well as how they make meaning of the heteronormative order that underpins their everyday reality. In this sense, considering their local embedment first seems to be quite a typical pattern of making informed decisions. And, although the same may hold true for many, regardless of their imagined position on the ladder of normalcy, Ewa sees her situation through the prism of how she may be perceived by normals, as well as related legal regulations that largely discriminate the LGBT community in Poland (also see: Mizielińska, Struz- 
ik, and Król 2017; Mizielińska and Stasińska 2020). The same anxieties and frustration are voiced in Paulina's narrative excerpt:

Before I got pregnant, we first had to plan everything so that all those issues wouldn't arise at a later stage... For example, I didn't want to [undergo insemination] until we had a specific sum of money set aside, because, you know, I said to myself that our country is what it is, and you need to be prepared for anything. I don't know what will happen in six months, in two years, in five years...but I simply needed to know that shall anything happen, we would be able to leave and not worry about the child.

[Paulina, biological mother, 2013]

Paulina addresses how having embraced context-related specificity of their situation shaped the way they acted while turning parenting desires into parenting reality. Anticipating "all those issues," not only did they focus on meticulous planning of every step of their way they also viewed their financial capital as one of the few resources at their disposal by means of which they were able to manage the anticipated conflictive encounters, or-leave. In this sense, accumulating such capital can translate into increasing the participants' sense of agency, ${ }^{20}$ but-in the case of failing to do so-it can also have a great impact on their decision of becoming parents or remaining childfree (see: Mezey 2013; Mizielińska and Stasińska 2020).

What surfaces from the above reflections is that the participants' pragmatic choices are, in reality, associated with high emotional costs. Especially so that

\footnotetext{
${ }^{20}$ To avoid anticipated homophobia, they often choose private healthcare, hire a babysitter and/or send their children to private (and, for the most part, expensive) nursery schools, where-as clients - they can control the interactions, to at least some degree.
}

they tend to interpret the former as largely restricted by the unfavorable legal situation and socio-cultural climate-as shaped by the heteronormative framework. As Iza recounts:

It shouldn't be like that. It should be a joyous time for you and yours. And yet, I was thinking whether we had enough money, whether our decision wouldn't put [their child to be born] in danger. It's not that I have any regrets, not in a million years. It's just that it shouldn't be like that.

[Iza, non-biological mother, 2014]

Thus, although their choices represent for the participants the best ones they could have made, their related fears and anxieties do not "fade away." As Lena's utterance illustrates, open-ended reflecting on the choices they make may be a very emotional process, possibly the one that shapes their parenting decision-making process the most. In this sense, the way they engage in the process at hand can be seen in terms of paving their path beyond the heteronormative framework, where no to little ready-made interactional scripts are available.

It is true that at some point it narrows down to such... rational questions, I would say. But... No, in fact it's not the way I was about to say, because it's not that once that decision is made, you move on. It's been a while since then, since we've been at that stage, so I guess that some things... that we have worked some issues out since then, but figuring out whether what you do is right is something that one never forgets. Because, on the one hand, you know what you want, you know that you want to be a good parent to that child, and on the other hand, you're not certain whether what you do is right, and it goes on and on... I think it's like... it never completely fades away.

[Lena, biological mother, 2018] 


\section{Concluding Remarks}

Based on my six-year study on two-mother planned families in Poland, the aim of this article was to shed light on how same-sex female couples navigating within the unfavorable socio-cultural climate engage in the parenting decision-making process-something that is largely viewed as the natural step for those who wish to enlarge their heteronormative families. Drawing on the analysis of how they negotiate their moral right to become mothers, as well as related reflections on the role their support networks play in shaping the process at hand, my aim was to illustrate to what degree the local-specific heteronormative framework may factor into the way they make meanings. As illuminated, although they wish to start a normal family, they have embraced that they do not quite fit in structurally as non-heteronormative parents, which leaves relatively little space for building their sense of agency and related ontological security while venturing beyond the heteronormative framework in the process of becoming parents-when compared to what heteronormative couples enjoy in that respect. Of course, due to recognizing one's emotional struggles when making parental choices in the context of the unfavorable socio-cultural climate that largely shapes the pool of options from which to choose, that does not come as a surprise for the participants. Rather, they embrace how different from what is considered normal their situation may be seen, as well as what their decisions in that regard may entail. Furthermore, although very emotional in nature, their parenting decision-making process seems to be held down by a number of pragmatic choices that they can make while anchoring their moral right to become mothers. In this sense, understanding their decisions to enlarge the family in terms of a turning point can be viewed in relation to embracing that from now on they will have to learn anew how to deal with being different, only this time they need to take one more person into account, the one being dependent on them. Thus, their anxieties related to predicting the possibility of experiencing some form of homophobia can be viewed in terms of their fear of becoming discredited, instead of being discreditable, due to the interpretation of their family as not fitting in the moral fabric of (traditional) society (Goffman 1986). In a nutshell, their agitation in that regard can be explained by their anticipation that a same-sex family with a child can be seen as lower down on the ladder of normalcy (Warner 1999). Additionally, as they believe, hiding the nature of their family-in front of certain people and in certain situations-may be more complex in the event of enlarging the family. ${ }^{21}$ What further complicates the way the women in this study make meaning of their situation is their understanding of their roles as parents, that is, those who should shield their children, not expose them to danger. That is why, when taking on the perspective of the generalized other, they-step by step-negotiate their moral right to become mothers and-in the process of giving meaning (e.g., framing their motherhood as reflexive and meticulously planned) and encountering their support networks-build new interpretational scripts, which allows them to normalize their situation. Additionally, a surfacing remark that structures the insights I have offered in this paper is that the case of Polish samesex female couples who engage in the parenting decision-making process aptly illustrates how parenting is socially constructed.

This article sheds light on the process of family formation from its genesis, taking into account context-specific factors that shape the way same-sex female cou-

\footnotetext{
${ }^{21}$ The issue of everyday practices of managing their family's visibility, as well as of the results of (anticipating) decoding its constellation is discussed in: Wojciechowska 2020a.
} 
ples in Poland engage in the process at hand. Still, due to the homogeneity of the research sample, that is, couples who enjoy social, cultural, and economic capitals allowing them the affordability to enlarge their families, it does not address the situation of those who are single and/or less privileged, which, I believe, should

\section{References}

Berger, Peter L. and Thomas Luckmann. 1966. The Social Construction of Reality. Harmondsworth: Penguin Books.

Blumer, Herbert. 1969. Symbolic Interactionism: Perspective and Method. Berkeley, CA: University of California Press.

Bos, Henny, Frank van Balen, and Dymphna C. van den Boom. 2007. "Child Adjustment and Parenting in Planned Lesbian-Parent Families." American Journal of Orthopsychiatry 77(1):38-48.

Brown, Rhonda and Amaryll Perlesz. 2007. "Not the 'Other' Mother. How Language Constructs Lesbian Co-Parenting Relationships." Journal of GLBT Family Studies 3(2-3):267-308.

CBOS. 2017. "Attitude to People of Homosexual Orientation." Retrieved July 27, 2020 (https://www.cbos.pl/PL/publikacje/ public_opinion/2017/12_2017.pdf).

Chambers, Deborah. 2006. New Social Ties. Contemporary Connection in a Fragmented Society. London: Palgrave Macmillan.

Charmaz, Kathy. 2006. Constructing Grounded Theory. A Practical Guide through Qualitative Analysis. Thousand Oaks, CA: Sage.

Clarke, Victoria. 2002. "Sameness and Difference in Research on Lesbian Parenting." Journal of Community $\mathcal{E}$ Applied Social Psychology 12(3):210-222.

Clarke, Victoria. 2008. “From Outsiders to Motherhood to Reinventing the Family: Constructions of Lesbian Parenting in the Psychological Literature-1886-2006." Women's Studies International Forum 31(2):118-128.

Coleman, Marilyn and Lawrence Ganong, eds. 2004. Handbook of Contemporary Families. Considering the Past, Contemplating the Future. Thousand Oakes, CA: Sage. be one of the concerns for future research. In addition, it would be insightful to learn about the situation of those who, although considered becoming parents, did not decide to do so. Answering those, and related, questions can inform our understanding of how and why same-sex female families are changing.

Denzin, Norman. 1978. Sociological Methods: A Sourcebook. New York: McGraw Hill.

Giddens, Anthony. 1991. Modernity and Self-Identity. Self and Society in the Late Modern Age. Stanford, CA: Stanford University Press.

Glaser, Barney and Anselm L. Strauss. 1967. The Discovery of Grounded Theory. New York: Aldine Publishing.

Goffman, Erving. 1959. The Presentation of Self in Everyday Life. New York: Anchor Books.

Goffman, Erving. 1986. Stigma: Notes on the Management of Spoiled Identity. New York, London, Toronto: A Touchstone Book.

Goldberg, Abbie and Katherine Allen, eds. 2013. LGBT-Parent Families. Innovations in Research and Implications for Practice. New York, Heidelberg, Dordrecht, London: Springer.

Goldberg, Abbie E., Jordan B. Downing, and Hannah B. Richardson. 2009. "The Transition from Infertility to Adoption: Perceptions of Lesbian and Heterosexual Couples." Journal of Social and Personal Relationships 26(6-7):938-963.

Gouliquer, Lynne, Carmen Poulin, and Jennifer McWilliams. 2020. "Othering of Full-Time and Volunteer Women Firefighters in the Canadian Fire Services." Qualitative Sociology Review 16(3):48-69.

Herek, Gregory M. 2004. “Beyond 'Homophobia': Thinking about Sexual Prejudice and Stigma in the Twenty-First Century." Sexuality Research and Social Policy 1(2):6-24.

Herek, Gregory M. 2007. “Confronting Sexual Stigma and Prejudice: Theory and Practice." Journal of Social Issues 63(4):905-925. 
Johnson, Suzanne M. 2012. "Lesbian Mothers and Their Children: The Third Wave." Journal of Lesbian Studies 16(1):45-53.

Kleinknecht, Steven. 2007. “An Interview with Robert Prus: His Career, Contributions, and Legacy as an Interactionist Ethnographer and Social Theorist." Qualitative Sociology Review 3(2):221-288.

Konecki, Krzysztof T. 2000. Studia z metodologii badań jakościowych. Teoria ugruntowana [Studies in the Methodology of Qualitative Research. Grounded Theory]. Warsaw: Wydawnictwo Naukowe PWN.

Konecki, Krzysztof T. 2018. Advances in Contemplative Social Research. Lodz: Wydawnictwo UŁ / Cracow: Jagiellonian University Press.

Linder, Janet. 2011. Lesbian Non-Biological Mothers During the Transition to Parenthood. PhD Dissertation. Sanville Institute for Clinical Social Work and Psychotherapy, Berkeley.

Lubbe, Carien. 2013. "LGBT Parents and Their Children: Non-Western Research and Perspectives." Pp. 209-223 in LGBT-Parent Families. Innovations in Research and Implications for Practice, edited by A. E. Goldberg and K. R. Allen. New York, Heidelberg, Dordrecht, London: Springer.

Majka-Rostek, Dorota. 2008. Zwiazki homoseksualne. Studium socjologiczne [Homosexual Relationships. A Sociological Study]. Warsaw: Difin.

Majka-Rostek, Dorota. 2011. “Same-Sex Couples in Poland: Challenges of Family Life." Journal of GLBT Family Studies 7:285-296.

Majka-Rostek, Dorota. 2014. “Macierzyństwo lesbijek - wybrane konteksty społeczne [Lesbian Motherhood-Selected Social Contexts]." Studia Socjologiczne 215(4):59-76.

Mezey, Nancy J. 2008. New Choices, New Families: How Lesbians Decide about Motherhood. Baltimore, MD: The Johns Hopkins University Press.

Mezey, Nancy J. 2013. "How Lesbians and Gay Men Decide to Become Parents or Remain Childfree." Pp. 59-70 in LGBT-Parent Families. Innovations in Research and Implications for Practice, edited by A. E. Goldberg and K. R. Allen. New York, Heidelberg, Dordrecht, London: Springer.

Mizielińska, Joanna and Agata Stasińska. 2020. “Negotiations between Possibilities and Reality: Reproductive Choices of Families of Choice in Poland." European Journal of Women's Studies. Retrieved March 20, 2021 (https://journals.sagepub. com/doi/10.1177/1350506819887765).
Mizielińska, Joanna, Marta Abramowicz, and Agata Stasińska. 2015. Families of Choice in Poland. Family Life of Non-Heterosexual People. Warsaw: IP PAN.

Mizielińska, Joanna, Justyna Struzik, and Agnieszka Król. 2017. Różnym głosem. Rodziny z wyboru w Polsce [n a Different Voice. Families of Choice in Poland]. Warsaw: Wydawnictwo Naukowe PWN.

Morgan, David H. J. 1996. Family Connections: An Introduction to Family Studies. Cambridge: Polity Press.

Paldron, Morgan. 2014. The Other Mother: An Exploration of Non-Biological Lesbian Mothers' Unique Parenting Experience. PhD Dissertation. University of Minnesota, Minneapolis.

Park, Shelly M. 2013. Mothering Queerly, Queering Motherhood. Resisting Monomaternalism in Adoptive, Lesbian, Blended, and Polygamous Families. Albany, NY: State University of New York Press.

Patterson, Charlotte. 1995. "Families of the Lesbian Baby Boom: Parents' Division of Labor and Children's Adjustment." Developmental Psychology 31(1):115-123.

Peterson, Gary and Kevin Bush, eds. 2013. Handbook of Marriage and the Family. New York, Heidelberg, Dordrecht, London: Springer.

Prus, Robert. 1997. Subcultural Mosaics and Intersubjective Realities. An Ethnographic Research Agenda for Pragmatizing the Social Sciences. Albany, NY: State University of New York Press.

Prus, Robert and Scott Grills. 2003. The Deviant Mystique. Westport, CT: Praeger.

Ryan-Flood, Róisín. 2009. Lesbian Motherhood: Gender, Families and Sexual Citizenship. Basingstoke: Palgrave Macmillan.

Slany, Krystyna. 2006. Alternatywne formy życia matżeńsko-rodzinnego w ponowoczesnym świecie [Alternative Forms of Marriage and Family Life in the Postmodern World]. Cracow: Nomos.

Slater, Suzanne. 1995. The Lesbian Family Cycle. New York: Free Press.

Stacey, Judith. 1996. In the Name of the Family: Rethinking Family Values in the Postmodern Age. Boston, MA: Beacon Press.

Stacey, Judith and Timothy Biblarz. 2001. "(How) Does the Sexual Orientation of Parents Matter?" American Sociological Review 66(2):159-183.

Stets, Jan E. and Jonathan H. Turner. 2006. Handbook of the Sociology of Emotions. New York: Springer. 
Strauss, Anselm L. 1993. Continual Permutations of Actions. New York: Aldine de Gruyter.

Warner, Michael. 1999. The Trouble with Normal. Cambridge, MA: Harvard University Press.

Weeks, Jeffrey, Brian Heaphy, and Catherine Donovan. 2001. Same Sex Intimacies. Families of Choice and Other Life Experiments. London: Routledge.

Weston, Kath. 1991. Families We Choose: Lesbians, Gays, Kinship. New York: Columbia University Press.

Wojciechowska, Magdalena. 2014. "Uczenie się 'normalności' w sytuacji doświadczania symbolicznego wykluczenia przykład badań nad rodzicielstwem jednopłciowym kobiet w społeczeństwie heteronormatywnym [Acquiring the Sense of 'Normality' within the Context of Experiencing Symbolic Exclusion-The Case of Study on Same-Sex Female Parenting in Heteronormative Society]." Studia Socjologiczne 214(3):127-157.

Wojciechowska, Magdalena. 2015. “O działaniu w ramach konceptualnej niewidzialności. Przykład badań nad macierzyństwem jednopłciowym w doświadczeniu matek niebiologic- znych [Acting within the Context of Conceptual Invisibility. How Non-Biological Lesbian Mothers Experience Motherhood]." Przegląd Socjologii Jakościowej 11(4):114-145.

Wojciechowska, Magdalena. 2020a. Dwie matki jednego dziecka [Two Mothers of One Child]. Lodz: Wydawnictwo Uniwersytetu Łódzkiego.

Wojciechowska, Magdalena. 2020b. “How Non-Heteronormative Mothers Negotiate Meaning: Experiencing and Contextualizing Invisibility." Qualitative Sociology Review 16(4):146-163.

Wycisk, Jowita. 2017. "Heteroseksizm i jego znaczenie dla pracy psychologicznej z rodzinami LGB. Sytuacja w Polsce [Heterosexism and Its Significance for Psychological Work with LGB Families. The Situation in Poland]." Psychologia Społeczna 12 4(43):415-429.

Zhabenko, Alisa. 2014. "Reproductive Choices of Lesbian-Headed Families in Russia: From The Last-Soviet Period to Contemporary Times." lambda nordica 3-4:54-85.

Zhabenko, Alisa. 2019. “Russian Lesbian Mothers: Between “Traditional Values' and Human Rights." Journal of Lesbian Studies 29(3):321-335.

\title{
Cytowanie
}

Wojciechowska, Magdalena. 2021. “Do We Have the Right? How Polish Same-Sex Female Families Negotiate Turning Parenting Desires into Parenting Reality." Przeglad Socjologii Jakościowej 17(2):62-83. Retrieved Month, Year (www.przegladsocjologiijakosciowej.org). DOI: https://doi.org/10.18778/1733-8069.17.2.04

\section{Czy mamy prawo? Od myślenia o do urzeczywistniania pragnienia macierzyństwa - jak polskie pary nieheteronormaty wne negocjują możliwość powiększenia rodziny}

\begin{abstract}
Abstrakt: Celem artykułu jest refleksja na temat tego, jak odczytywanie zjawisk zachodzących na poziomie mikro i makro współkształtuje proces podejmowania decyzji o powiększeniu rodziny w przypadku jednopłciowych par kobiet w Polsce. Odnosząc się do wyników sześcioletnich badań z udziałem rodzin planowanych, koncentruję się na przedstawieniu doświadczeń kobiet na etapie myślenia o możliwości powiększenia rodziny w kontekście ich chęci „wpasowania” rodziny nieheteronormatywnej z dzieckiem w tkankę społeczną. Akcent położony jest na zilustrowanie tego, jak badane - działając w ramach niesprzyjających warunków społeczno-kulturowych - nadają swoim doświadczeniom na tym polu znaczenie, negocjując moralne prawo do zostania matkami. Jednocześnie analizie poddane zostają ukontekstualizowane czynniki interakcyjne, które wpływają na myślenie o macierzyństwie nieheteronormatywnym w kategoriach możliwości. A zatem przybliżane jest to, w jaki sposób jednostki wychodzące poza umowną ramę heteronormatywności podejmują decyzję o powiększeniu rodziny, co - w przypadku osób mieszczących się w jej obszarze - uznawane jest za normalne.
\end{abstract}

Słowa kluczowe: macierzyństwo nieheteronormatywne w Polsce; proces podejmowania decyzji o macierzyństwie; heteronormatywność jako rama znaczeń; nadawanie znaczenia; interakcjonizm symboliczny 